\title{
Symptomer og diagnostikk av koronarsykdom hos kvinner
}

\begin{abstract}
Sammendrag
Bakgrunn. Koronarsykdom hos kvinner skiller seg fra sykdom hos menn både når det gjelder symptomer, klinisk presentasjon, verdi av diagnostiske tester og behandling. Artikkelen gir en oversikt over symptomer og diagnostikk ved koronarsykdom hos kvinner og diskuterer de diagnostiske prosedyrer vi har til rådighet.
\end{abstract}

Materiale og metode. Artikkelen er basert på et ikke-systematisk litteratursøk i PubMed.

Resultater. Kvinner rammes av koronarsykdom gjennomsnittlig ca. ti år senere enn menn, men kvinner med risikofaktorer mister fort denne kjønnsfordelen, og forekomsten av hjerteinfarkt hos kvinner med multiple risikofaktorer er på nivå med forekomsten hos menn. Kvinner med koronarsykdom har sjeldnere brystsmerter som hovedsymptom enn menn og kan ha mer uspesifikke symptomer. De tradisjonelle ikke-invasive unders $\varnothing$ kelsene har lavere diagnostisk treffsikkerhet hos kvinner enn hos menn. Kvinner har også lavere forekomst av stenoser ved koronar angiografi og synes å ha mer diffust utbredt aterosklerose enn menn. Dette gjør diagnostikken vanskelig. Koronar CT-angiografi er en lovende diagnostisk undersøkelse, men få kvinner har vært inkludert i studier som har undersøkt metodens presisjon, og strålingsdosen er fortsatt relativt høy.

Fortolkning. Vi anbefaler en utredningsstrategi med vekt på risikostratifisering av pasientene og deretter identifisering av de pasientgrupper som trenger invasiv undersøkelse. Nye teknikker for påvisning av koronarsykdom hos kvinner imøteses.

\section{Sigrun Halvorsen}

sigrun.halvorsen@ulleval.no

Hjertemedisinsk avdeling

Oslo universitetssykehus, Ullevål

0407 Oslo

\section{Cecilie Risøe}

Hjertemedisinsk avdeling

Oslo universitetssykehus, Rikshospitalet

Til tross for betydelig nedgang i hjerte- og kardødeligheten i Norge er hjerte- og karsykdom fortsatt ledende dødsårsak for både kvinner og menn (1). $40 \%$ av norske kvinner dør av hjerte- og karsykdom. Dette gir høyere dødstall enn alle kreftformer til sammen. Koronar eller iskemisk hjertesykdom (hjerteinfarkt og angina pectoris) er viktigste årsak innen gruppen hjerte-kar-sykdom, fulgt av hjerneslag som en god nummer to.

Koronarsykdom hos kvinner skiller seg fra sykdom hos menn både når det gjelder symptomer, klinisk presentasjon, verdi av diagnostiske tester, prognose og behandling. For å stille diagnosen koronarsykdom hos kvinner på et tidlig tidspunkt og for å behandle kvinner optimalt trengs kunnskap om de kjønnsspesifikke forskjellene. Internasjonalt drives utstrakt forskning på dette området. I denne artikkelen gis en oversikt over hva vi per i dag vet om symptomer og diagnostikk ved koronarsykdom hos kvinner.

\section{Materiale og metode}

Grunnlaget for artikkelen er et ikke-systematisk litteratursøk i PubMed med et skjønnsmessig utvalg av artikler basert på forfatternes kliniske erfaring innen feltet.

\section{Forekomst og risikofaktorer}

Kvinner får hjerteinfarkt gjennomsnittlig ca. ti år senere enn menn (2), og både insidensen og mortaliteten av hjerteinfarkt er hele livet lavere hos kvinner enn hos menn $(1,3)$. Denne kjønnsfordelen faller bort for kvinner med multiple risikofaktorer (4). På grunn av den økende andel kvinner med risikofaktorer som overvekt og diabetes og den høye levealderen for kvinner, er det svært mange kvinner som før eller siden rammes av koronarsykdom (1).

De klassiske risikofaktorene for koronarsykdom, som høyt blodtrykk, høyt LDLkolesterol og røyking, er viktige risikofaktorer hos kvinner på samme måte som hos menn (4). Flere studier har vist at røyking er en ekstra sterk risikofaktor hos yngre kvin- ner (4-5). Både høye nivåer av triglyserider og lavt HDL-kolesterol har i noen studier vist seg som mer potente risikofaktorer for iskemisk hjertesykdom hos kvinner enn hos menn (4).

Diabetes er sannsynligvis den viktigste risikofaktoren for utvikling av koronarsykdom hos kvinner. Den aldersjusterte risiko for død av koronar sykdom er 3-4 ganger høyere hos kvinner med diabetes enn hos kvinner uten (6), og risikoøkningen forbundet med diabetes er $50 \%$ større for kvinner enn for menn (6-7). Årsaken til dette er uklar. Kvinner med metabolsk syndrom har en risiko som ligger mellom den for kvinner med normalt glukosenivå og den for diabetikere (4). Kvinner med autoimmune lidelser, eksempelvis revmatoid artritt, har økt forekomst av aterosklerotisk sykdom $(4,8)$. Dette antas å ha sammenheng med kronisk inflammasjon. Hormonenes rolle som beskyttelsesfaktor mot koronarsykom er uavklart, men endogen østrogenmangel hos yngre kvinner synes å være en sterk risikofaktor (4). Risikoen ved hormonell substitusjonsbehandling av postmenopausale kvinner er fortsatt omdiskutert og uavklart.

En kombinasjon av mange risikofaktorer på én gang (clustering) er vanligere hos kvinner enn hos menn, f.eks. overvekt, hypertensjon og dyslipidemi. En slik kombinasjon av risikofaktorer vil lett kunne øke kvinners risiko til menns nivå.

\section{Klinisk presentasjon}

Kvinner synes å ha mindre tendens enn menn til utvikling av ST-elevasjonshjerteinfarkt, men utvikler i større grad ikke-STelevasjonshjerteinfarkt eller ustabil angina pectoris (9-10). Kvinnene har også mer komorbiditet enn menn når de får sitt første hjerteinfarkt (diabetes, hypertensjon og/eller

\section{Hovedbudskap}

- Symptomene hos kvinner er mer varierte og uspesifikke enn hos menn

- Kvinner med risikofaktorer og koronarsuspekte symptomer må undersøkes nærmere

- Ikke-invasive undersøkelsesmetoder har lavere diagnostisk presisjon hos kvinner enn menn

- Teknikker for påvisning av koronarsykdom hos kvinner må bedres 
hjertesvikt). Stabil angina synes å affisere kvinner like hyppig som menn (11). Noen studier rapporterer endog høyere forekomst av angina hos postmenopausale kvinner enn hos menn på samme alder (12).

\section{Symptomer}

Kvinner med koronar hjertesykdom synes å ha mer varierte og uspesifikke symptomer enn menn (13-15). Sentrale, anstrengelsesrelaterte brystsmerter med utstråling til skuldre og arm, som er det klassiske symptomet på koronar hjertesykdom, er sjeldnere til stede hos kvinner enn hos menn. I en studie av 2073 pasienter med akutt hjerteinfarkt fant man at bare $54 \%$ av kvinnene hadde brystsmerter som sitt hovedsymptom, versus $69 \%$ av mennene (16). I en fersk samleanalyse av publiserte artikler i perioden 1970-2005 fant man fravær av brystsmerter hos $37 \%$ av kvinner med akutt hjerteinfarkt versus $27 \%$ hos menn (17).

Kvinner får ofte mer atypiske brystsmerter i form av verk i rygg, nakke, kjeve, armer eller epigastriet, eller uspesifikke symptomer som slitenhet, tungpustethet, kaldsvetting, svimmelhet eller fordøyelsesplager (17). Mange kvinner har også i ukene før utvikling av et hjerteinfarkt varselssymptomer som uvanlig trøtthet/slitenhet, tungpustethet, fordøyelsesplager eller søvnproblemer (18).

Det er også kjønnsforskjeller i persepsjon av smerte og i terskelen for rapportering av symptomer (12, 19). Sammen med den større variasjonen i symptomatologi hos koronarsyke kvinner kan dette medvirke til at diagnosen koronarsykdom forsinkes eller overses.

\section{Diagnostikk}

Anamnese med risikovurdering

Nøyaktig anamnese med kartlegging av symptomer og risikofaktorer er grunnleggende i diagnostikken. Det er verdt å understreke betydningen av kartlegging av pasientens risikofaktorer. Symptomatiske kvinner med risikofaktorer må tas alvorlig og undersøkes nærmere.

Det er utviklet flere skåringssystemer til hjelp ved beregning av individuell risiko for kardiovaskulær sykdom. Det mest brukte i dag er det europeiske risikodiagrammet SCORE (20). Fordi SCORE overestimerer den kardiovaskulære dødeligheten i Norge, er det utviklet en ny risikomodell basert på norske data, NORRISK (21). Denne beregner tiårsrisikoen for kardiovaskulær død tilpasset risikofaktornivå og dødelighetsnivå i Norge. Det er viktig å være oppmerksom på at både SCORE og NORRISK bygger på dødelighetsdata, ikke på sykdomsforekomst. Pasientalder veier særskilt tungt, og nesten ingen under 50 år vil klassifiseres som personer med høy absolutt risiko for å dø i løpet av nærmeste tiår. Dette gjelder i enda større grad for kvinner enn for menn. Hos yngre personer anbefales derfor bruk av relativ risiko, og både SCORE og NORRISK inneholder tabeller over dette. Relativ risiko kan brukes til å vise at yngre mennesker med lav totalrisiko har forhøyet risiko sammenliknet med andre på deres alder. Når personen blir eldre, vil en høy relativ risiko omformes til en høy totalrisiko. Denne tankegangen gjenspeiles i Helsedirektoratets nye nasjonale retningslinjer for individuell primærforebygging av hjerte- og karsykdommer (22).

Risikofaktoren diabetes er ikke inkludert i noen av risikomodellene. Det anbefales i de nyeste europeiske retningslinjene at risikoen settes fem ganger høyere for kvinner med diabetes $\mathrm{i}$ forhold til den angitte risikoen $\mathrm{i}$ SCORE-diagrammet (20). Det samme anbefaler NORRISK (21).

C-reaktivt protein (CRP) synes å bedre risikoklassifiseringen av kvinner, og dette gjelder især for kvinner med intermediær tiårsrisiko (23). Det er bl.a. vist at kvinner med metabolsk syndrom og høyt nivå av høysensitiv CRP (hsCRP) har like høy risiko som diabetiske kvinner. Amerikanerne har nylig utviklet en kvinnespesifikk risikoskår, Reynold's Risk Score, som sies å forbedre presisjonen av risikovurderingen hos kvinner (24). I tillegg til de klassiske risikofaktorer har denne modellen inkludert diabetes, høysensitiv CRP og familiehistorie om prematur kardiovaskulær sykdom.

Flere ikke-invasive undersøkelser som kan være til hjelp i risikoklassifiseringen, er lansert de siste årene. De best etablerte av disse er bestemmelse av intima-media-tykkelse i arteria carotis og koronar kalsiumskår (Coronary Calcium Score, CCS). Intimamedia-tykkelse kan måles med ultralyd og har høy positiv prediktiv verdi, høy sensitivitet og høy spesifisitet for koronarsykdom hos symptomatiske kvinner (25). Risiko for koronarsykdom hos kvinner med intimamedia-tykkelse $>1,07 \mathrm{~mm}$ var $\mathrm{i}$ en studie mer enn sju ganger høyere enn risikoen hos kvinner med intima-media-tykkelse under denne terskelverdien (25). Bestemmelse av intima-media-tykkelse anbefales nå av mange som et nyttig tillegg til den kliniske risikovurderingen (26), men har foreløpig fått liten utbredelse hos oss.

Koronar kalsiumskår kvantifiserer mengden kalk i koronararterier. Koronar kalk er nesten alltid til stede ved angiografisk signifikant koronarsykdom, så sensitiviteten er høy, men spesifisiteten er lav, ettersom nærvær av kalk ikke er identisk med stenoserende koronarsykdom (26). Kalsiumskår kan brukes som markør for prognose hos asymptomatiske kvinner: lav skår er assosiert med lav risiko for kardiovaskulære hendelser. Men svært få studier har inkludert kvinner. Det betyr at kvinnespesifikke grenser for hva som er høy og hva som er lav kalsiumskår foreløpig ikke er sikkert etablert Internasjonalt anbefales koronar kalsiumskår-testing kun til selekterte kvinner med middels risiko $(4,26)$. I Norge er metoden foreløpig lite benyttet, og det kan synes rimelig å avvente ytterligere dokumentasjon før den eventuelt tas mer i bruk.

\section{Undersøkelser for påvisning av koronar iskemi}

Dersom anamnese og risikovurdering gir holdepunkter for at pasienten har middels eller høy risiko for koronarsykdom, er det aktuelt å gå videre med ikke-invasive eller invasive undersøkelser.

Arbeids-EKG. Dette er en rimelig og enkel undersøkelse å utføre og anbefales fortsatt som førstevalg ved undersøkelse av symptomatiske kvinner (fig 1) (12, 27). Det forutsetter imidlertid at kvinnen har moderat til høy arbeidstoleranse, tilnærmet normale funn ved hvile-EKG og ikke bruker digitalispreparater, ellers blir tolkingen svært vanskelig. Det er viktig å være klar over at arbeids-EKG har lavere sensitivitet og spesifisitet for påvisning av signifikant koronarsykdom hos kvinner enn hos menn (4, 26-28). Spesifisiteten varierer avhengig av studiepopulasjonen (tab 1) (26), med en gjennomsnittlig spesifisitet på $70 \%$ i en metaanalyse (28). Det betyr at minst $30 \%$ av positive funn ved arbeids-EKG er falskt positive med hensyn til påvisning av signifikant koronarsykom.

Sensitiviteten for påvisning er rapportert å være 53-61 \% (28). Positiv prediktiv verdi er i de fleste studier under $50 \%$ for kvinner og ca. $70 \%$ for menn (26), mens negativ prediktiv verdi er høy (12). Lav positiv prediktiv verdi innebærer at kvinner med positiv test må henvises til videre undersøkelser. Den lavere treffsikkerheten ved arbeidsEKG hos kvinner skyldes delvis deres lavere forekomst av koronarsykdom i yngre aldersgrupper, delvis inkonklusive resultater pga. redusert arbeidstoleranse. Hormonelle faktorer er også antatt å spille en rolle. En digitoksinliknende effekt av endogent østrogen er postulert å gi høyere forekomst av falskt positive resultater hos premenopausale kvinner $(4,26)$. Det samme kan opptre ved hormonell substitusjonsbehandling av postmenopausale kvinner. Økt sympatikustonus hos yngre kvinner kan gi uspesifikke ST-Tforandringer. Falskt positivt EKG-funn hos kvinner avtar med økende alder.

Stressmyokardperfusjonsscintigrafi. Ved stressmyokardperfusjonsscintigrafi, også betegnet nukleærmedisinsk isotopundersøkelse eller stress-SPECT, benyttes farmakologisk stress med adenosin. Dette anbefales for kvinner med lav arbeidskapasitet, diabetes mellitus eller unormalt hvile-EKG samt ved inkonklusivt arbeids-EKG $(4,28)$. Undersøkelsen påviser reduksjoner i myokardperfusjon. Redusert myokardgjennomblødning opptrer tidligere enn både EKG-forandringer og endringer i veggbevegelighet ved ekkokardiografi. Overvekt og brystvev kan forstyrre tolkingen. Undersøkelsen har likevel relativt høy sensitivitet for påvisning av koronarsykdom hos kvinner ( $81 \%)$, men spesi- 
Tabell 1 Sensitivitet og spesifisitet ved ikke-invasive unders økelser hos kvinner

\begin{tabular}{lcc} 
& Sensitivitet (\%) & Spesifisitet $(\%)$ \\
\hline Arbeids-EKG $(26,28)$ & $53-61$ & $33-73$ \\
\hline Stressekkokardiografi $(4,26)$ & $86-90$ & $76-85$ \\
\hline Stressmyokardperfusjonsscintigrafi (4) & $77-87$ & $64-69$ \\
\hline 64-detektor-CT-angiografi (26) & $90-94$ & $75-97$
\end{tabular}

fisiteten er lav (66\%) (4). Strålingsdosen ved stressmyokardperfusjonsscintigrafi er relativt høy, ca. $12 \mathrm{mSv}$, omtrent det dobbelte av strålingsdosen ved koronar angiografi (29). Myokardperfusjonsscintigrafi er imidlertid ikke forbundet med de alvorlige akutte komplikasjoner som kan opptre ved invasive undersøkelser.

Stressekkokardiografi. Ved denne type undersøkelse påvises endringer i venstre ventrikkels veggbevegelighet ved iskemi og den synes å ha like stor treffsikkerhet i å påvise signifikant koronarsykdom hos kvinner som hos menn. En metaanalyse der man vurderte presisjonen av ekkokardiografi med farmakologisk stress, konkluderte med en sensitivitet på $86 \%$ og en spesifisitet på $79 \%$ for kvinner (30). En senere studie av stressekkokardiografi med dobutamin viste en enda høyere sensitivitet og spesifisitet, hhv. $90 \%$ og $85 \%$ for kvinner (31). Overvekt og kronisk obstruktiv lungesykdom (kols) kan gjøre innsyn vanskelig, og tolkingen påvirkes av undersøkers erfaring. Undersøkelsen er ressurs- og kompetansekrevende, og dens tilgjengelighet er relativt begrenset i Norge.
Arbeids-EKG, stressmyokardperfusjonsscintigrafi og stressekkokardiografi er også nyttige som prognostiske hjelpemidler. Stressmyokardperfusjonsscintigrafi og stressekkokardiografi har vist seg velegnet til å vurdere femårs hendelsesfri overlevelse hos kvinner med brystsmerter (4), og redusert maksimal arbeidskapasitet ved arbeids-EKG er en sterk prediktor for senere kardiovaskulær mortalitet $(4,32)$. Kobling av flere arbeids-EKG-parametre, som maksimal arbeidskapasitet, fall i hjertefrekvens etter avsluttet belastning og ST-segmentendringer, øker den prognostiske verdien av arbeids-EKG ytterligere.

\section{Koronarangiografi}

Dette er fortsatt gullstandarden for påvisning av koronare stenoser hos kvinner på samme måte som hos menn. Ved positive funn ved arbeids-EKG, stressmyokardperfusjonsscintigrafi eller stressekkokardiografi bør pasienten henvises videre til koronar angiografi. Ved symptomer og høy sannsynlighet for koronarsykdom bør man vurdere direkte henvisning til koronar angiografi.

Om alle kvinner med ustabil angina pectoris eller hjerteinfarkt uten ST-elevasjon

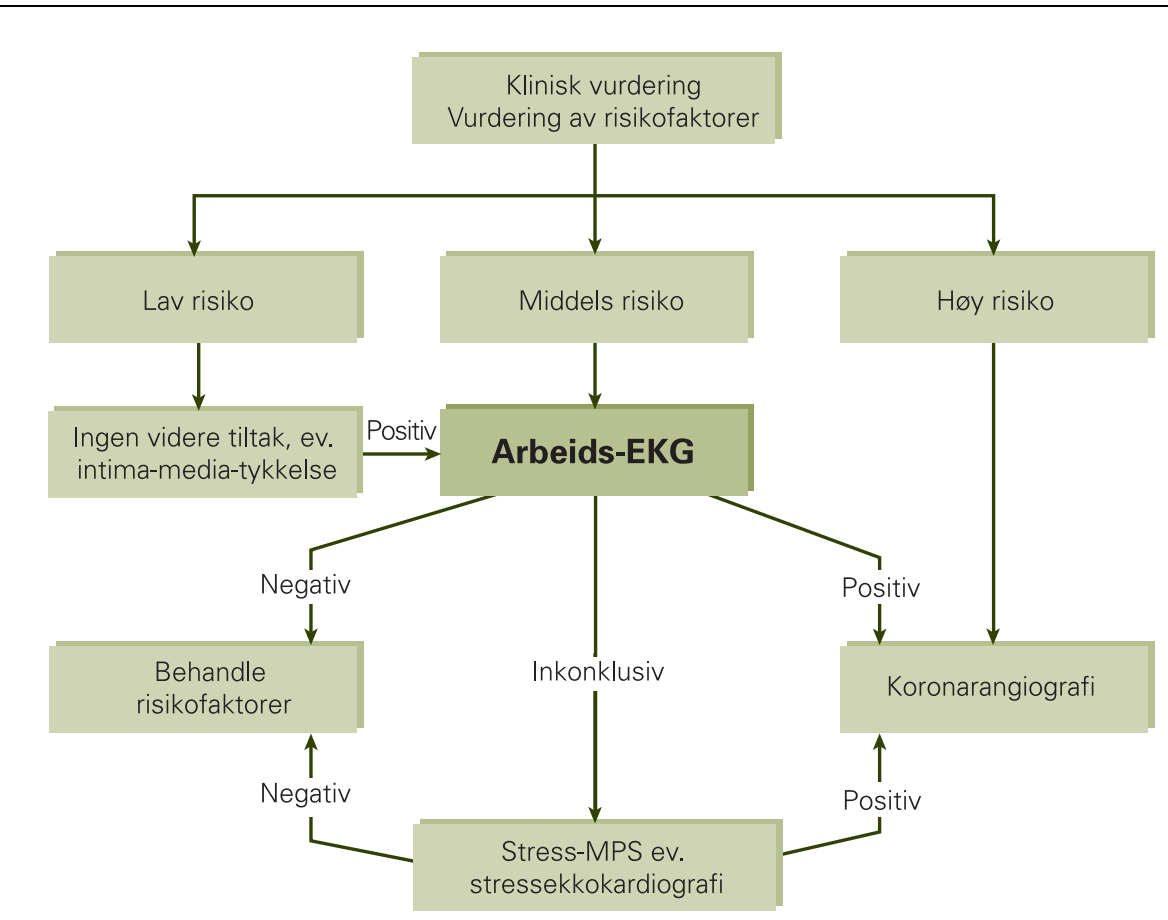

Figur 1 Artikkelforfatterens forslag til algoritme for utredning av kvinner med symptomer som gir mistanke om koronarsykdom. MPS = myokardperfusjonscintigrafi

skal henvises til tidlig invasiv utredning eller bør håndteres med en mer selektiv, iskemistyrt invasiv strategi, er uavklart. Ledende eksperter konkluderer i en fersk metaanalyse med at kvinner med akutt koronarsyndrom ikke synes å profittere på rutinemessig tidlig invasiv utredning på samme måte som menn (33). Studier med flere inkluderte kvinner er imidlertid nødvendig før man kan svare sikkert på dette spørsmålet.

Funn av signifikante koronare stenoser ved koronar angiografi sikrer diagnosen koronarsykdom hos kvinner på samme måte som hos menn. Det er imidlertid viktig å være klar over at åpne kransårer ved koronar angiografi ikke utelukker koronarsykdom og at ikke-signifikante stenoser også er tegn på koronarsykdom. Det er kjent fra mange studier at kvinner med gjennomgått hjerteinfarkt har lavere forekomst av signifikante stenoser enn menn $(33,34)$. I FRISC II-studien var det $25 \%$ av kvinnene som ikke hadde signifikante stenoser ved angiografi versus 9,5\% av menn (34). Også i studier av pasienter med stabil angina har man funnet at kvinner har lavere forekomst av signifikante koronare stenoser enn menn (35).

Det er holdepunkter for at kvinner utvikler en noe annerledes form for karsykdom enn menn (36-37). Koronararteriene hos kvinner synes å inneholde mer diffust utbredt aterosklerose med avleiringer langsetter karet. Disse avleiringene er ikke alltid synlige ved kontrastundersøkelse, men kan påvises ved mer avanserte teknikker som intravaskulær ultralyd. Metoden brukes i dag i forskningssammenheng og som tilleggsundersøkelse i spesielle tilfeller der koronar angiografi ikke gir god nok bildefremstilling av et mulig trangt område. I tillegg påvises oftere tegn på endret koronar vasoreaktivitet, som mikrovaskulær dysfunksjon og endoteldysfunksjon, hos kvinner enn hos menn (36). Koronar vasoreaktivitet kan undersøkes ved intrakoronar injeksjon av adenosin (coronary flow reserve) eller acetylkolin (koronar endotelial dysfunksjon). Teknikkene er imidlertid ressurskrevende og lite i bruk, og man leter etter enklere metoder.

\section{Nyere undersøkelsesteknikker}

Koronar CT-angiografi. Koronar CT-angiografi med multispiral-CT etter intravenøs injeksjon av kontrast er en lovende teknikk for kartlegging av koronarkar og plakkmorfologi. Sensitiviteten og spesifisiteten for påvisning av koronare stenoser med 64-detektor-maskiner er høy (tab 1), og negativ prediktiv verdi er vist å være $95-100 \%$ dersom man undersøker personer med lav til moderat økt risiko (26).

Noen studier viser tilnærmet like god presisjon av koronar CT-angiografi hos kvinner som hos menn, mens andre viser lavere sensitivitet og spesifisitet hos kvinner (26). Igjen er det slik at relativt få kvinner er inkludert i valideringsstudiene, så man har 
sparsomt med kvinnespesifikke data. Det er også viktig å være klar over at strålingsdosen ved koronar CT-angiografi $(5-20 \mathrm{mSv})$ foreløpig er større enn stråledosen ved koronar angiografi (2-6 mSv) (38), selv om forbedrede protokoller og strålesparende teknikker har redusert stråledosen de siste årene. Høye stråledoser kan gi økt risiko for senere utvikling av brystkreft hos kvinner (26). Undersøkelsen egner seg best til å utelukke koronarsykdom hos pasienter med middels sykdomsrisiko, da falskt positive funn utgjør et problem i lavrisikopopulasjonen (38). Med dagens relativt høye strålingsdose mener vi at det $\mathrm{i}$ alle fall hos yngre kvinner bør være like klar indikasjon for undersøkelsen som ved henvisning til koronar angiografi. Rask videreutvikling av CTteknologien med nye maskiner med høyere oppløsningsevne og reduserte stråledoser gjør at anbefalingene fort kan endre seg.

Magnetisk resonanstomografi. MR av hjertet med stresstesting (adenosin) er også en lovende metode for påvisning av myokardial iskemi. Undersøkelsen har svært høy oppløsningsevne, er fri for stråleeksposisjon og har evne til å påvise subendokardial iskemi som er det første som opptrer. En rekke undersøkelser de siste årene har vist moderat til høy diagnostisk treffsikkerhet av metoden, og det er nylig publisert en undersøkelse utført på 147 kvinner med funn av sensitivitet og spesifisitet på henholdsvis $84 \%$ og $88 \%$ (39). Undersøkelsen kan vise seg nyttig i diagnostikken av kvinner med brystsmerter, men i Norge er den foreløpig bare tilgjengelig i forskningsøyemed.

\section{Konklusjon}

Koronarsykdom hos kvinner skiller seg fra sykdom hos menn både når det gjelder betydningen av risikofaktorer, symptomer, klinisk presentasjon og verdi av diagnostiske tester. Større variasjon i symptomer og lavere utbredelse av koronare stenoser ved koronar angiografi gjør at sykdommen er vanskeligere å påvise $\mathrm{i}$ et tidlig stadium hos kvinner. Økt oppmerksomhet på kvinner med risikofaktorer for iskemisk hjertesykdom er nødvendig for at diagnosen skal bli stilt før sykdommen har utviklet seg for langt.

Et forslag til algoritme for utredning av kvinner med koronarsuspekte symptomer er vist i figur 1. Symptomatiske kvinner med risikofaktorer anbefales henvisning til arbeids-EKG, forutsatt god arbeidskapasitet og tilnærmet normalt hvile-EKG-funn. Kvinner med dårlig arbeidskapasitet, diabetes mellitus eller unormalt hvile-EKG-funn anbefales direkte henvisning til stressmyokardperfusjonsscintigrafi eller stressekkokardiografi. Disse undersøkelsene anbefales også ved usikre funn ved arbeids-EKG. Stressekkokardiografi er av kapasitetsgrunner mest benyttet som supplerende undersøkelse der det er tvil om den hemodynamiske betydningen av en angiografisk påvist stenose. Ved objek- tive tegn til moderat eller alvorlig iskemi ved stresstester skal kvinner henvises til koronar angiografi på samme måte som menn. Ved høy sannsynlighet for koronarsykdom bør direkte henvisning til koronar angiografi vurderes.

Koronar CT-angiografi er ikke inkludert $i$ algoritmen. Få kvinner er inkludert i de studier som har undersøkt metodens presisjon, og dagens relativt høye strålingsdose maner til forsiktighet hos yngre kvinner. CT-teknologien utvikler seg imidlertid raskt, og koronar CT-angiografi kan i fremtiden vise seg å bli en attraktiv metode for å utelukke koronarsykdom hos kvinner med middels risiko. Det samme gjelder MR av hjertet med stresstesting, som har høy diagnostisk presisjon og ingen stråleeksposisjon. Mikrovaskulær dysfunksjon kan være en utbredt årsak til iskemi og symptomer hos kvinner. Nye teknikker for vurdering av koronar mikrosirkulasjon imøteses.

En kombinasjon av flere risikoparametre og flere diagnostiske prosedyrer kan øke vår evne til påvisning av koronarsykdom hos kvinner. I fremtiden vil økt innsikt i kjønnsforskjeller når det gjelder patofysiologi og klinisk presentasjon samt forbedrede diagnostiske teknikker forhåpentligvis gjøre det lettere å stille diagnosen koronarsykdom hos kvinner.

Oppgitte interessekonflikter: Ingen

Vi takker Kjell A. Midtbø og Nils Einar Kløw for gjennomlesing og nyttige kommentarer.

\section{Litteratur}

Statistisk sentralbyrå. Dødsårsaker. www.ssb.no/ dodsarsak/ (7.5.2009)

2. Anand SS, Islam S, Rosengren A et al. Risk factors for myocardial infarction in women and men: insights from the INTERHEART study. Eur Heart 2008; 29: 932-40.

3. Tunstall-Pedoe H. Myth and paradox of coronary risk and the menopause. Lancet 1998; 351 : $1425-7$

4. Shaw LJ, Bairey Merz CN, Pepine CJ et al. Insights from the NHLBI-sponsored women's ischemia syndrome evaluation (WISE) study. Part I. J Am Coll Cardiol 2006; 47: 4-20S

5. Njølstad I, Arnesen E, Lund-Larsen PG. Body height, cardiovascular risk factors, and risk of stroke in middle-aged men and women. A 14-year follow-up of the Finnmark Study. Circulation 1996 94: 2877-82.

6. Huxley R, Barzi F. Woodward M. Excess risk of fatal coronary heart disease associated with diabetes in men and women: meta-analysis of 37 pro spective cohort studies. BMJ 2006; 332: 73-8.

7. Dale AC, Nilsen TI, Vatten $L$ et al. Diabetes mellitus and risk of fatal ischaemic heart disease by gender. Eur Heart J 2007; 28: 2924-9.

8. van Halm VP, Peters MJ, Voskuyl AE et al. Rheumatoid arthritis versus diabetes as a risk factor for cardiovascular disease, a cross sectional study. The CARRE Investigation. Ann Rheum Dis 2009: 68: $1395-400$

9. Hochman JS, Tamis JE, Thompson TD et al. Sex clinical presentation and outcome in patients with acute coronary syndromes. N Engl J Med 1999; 341: 226-32.

10. Rosengren A, Wallentin L, Gitt AK et al. Sex, age and clinical presentation of acute coronary syndromes. Eur Heart J 2004: 25: $663-70$.

11. Hemingway H, McCallum A, Shipley M et al. Incidence and prognostic implications of stable angina pectoris among women and men. JAMA 2006; 295 1404-11.

12. Fox K, Garcia MA, Ardissino D et al. Guidelines on the management of stable angina pectoris: executive summary: the Task Force on the Management of Stable Angina Pectoris of the European Society of Cardiology. Eur Heart J 2006; 27: 1341-81.

13. Milner KA, Funk M, Richards $S$ et al. Gender differences in symptom presentation associated with coronary heart disease. Am J Cardiol 1999: 84: $396-9$

14. Miller CL. A review of symptoms of coronary artery disease in women. J Adv Nurs 2002; 39: 17-23.

15. DeVon HA Ryan CJ, Ochs AL et al Symptoms across the continuum of acute coronary syndromes: differences between women and men. Am J Crit Care 2008; 17: 14-24.

16. Milner KA, Vaccarino V, Arnold AL et al. Gender and age differences in chief complaints of acute myocardial infarction. Am J Cardiol 2004; 93: 606-8.

17. Canto JG, Goldberg RJ, Hand MM et al. Symptom presentation of women with acute coronary syndromes: myth vs reality. Arch Intern Med 2007; 167: $2405-13$

18. McSweeney JC, Cody M, O'Sullivan P et al. Women's early warning symptoms of acute myocardial infarction. Circulation 2003; 108: 2619-23.

19. Nau DP. Ellis JJ, Kline-Rogers EM et al. Gender and perceived severity of cardiac disease: Evidence that women are «tougher». Am J Med 2005 118: $1256-61$

20. European Society of Cardiology. SCORE risk charts. www.escardio.org/Policy/prevention/tools/ health-toolkit/Pages/SCORE-Risk-Charts.aspx (7.5.2009).

21. Selmer R, Lindman AS, Tverdal A et al. Modell for estimering av kardiovaskulær risiko i Norge. Tidsskr Nor Legeforen 2008; 128: 286-90.

22. Helsedirektoratet. Nasjonale retningslinjer for individuell primærforebygging av hjerte- og kar sykdommer. IS-1550. www helsedirektoratet no/ kvalitetsforbedring/retningslinjer veiledere/publiserte (7.5.2009).

23. Cook NR, Buring JE, Ridker PM. The effect of including $\mathrm{C}$-reactive protein in cardiovascular risk prediction models for women. Ann Intern Med 2006; 145: $21-9$

24. Ridker PM, Buring JE, Rifai $N$ et al. Development and validation of improved algorithms for the assessment of global cardiovascular risk in women: the Reynolds Risk Score. JAMA 2007; 297 : $611-9$

25. Kablak-Ziembicka A, Przewlocki T, Tracz W et al. Gender differences in carotid intima-media thickness in patients with suspected coronary artery disease. Am J Cardiol 2005; 96: 1217-22.

26. Stangl V, Witzel V, Baumann G et al. Current diagnostic concepts to detect coronary artery disease in women. Eur Heart J 2008; 29: 707-17.

27. Mieres JH, Shaw LJ, Arai A et al. Role of non-invasive testing in the clinical evaluation of women with suspected coronary artery disease. Circulation 2005; 111: 682-96.

28. Kwok YS, Kim C, Grady D et al. Meta-analysis of exercise testing to detect coronary artery disease in women. Am J Cardiol 1999; 83: 660-6.

29. Marcassa C, Bax JJ, Bengel F et al. Clinical value cost-effectiveness, and safety of myocardial perfusion scintigraphy: a position statement. Eur Heart J 2008: 29.557-63.

30. Kim C, Kwok YS, Heagerty P et al. Pharmacologic stress testing for coronary disease diagnosis: A meta-analysis. Am Heart J 2001; 142: 934-44.

31. Schannwell CM, Lazica D, Plehn G et al. The current status of noninvasive cardiac diagnosis in women with suspected coronary heart disease. Med Klin (Munich) 2002; 97: 513-21.

32. Mora S, Redberg RF, Cui Y et al. Ability of exercise testing to predict cardiovascular and all-cause death in asymptomatic women: a 20 -year followup of the lipid research clinics prevalence study. JAMA 2003; 290: $1600-7$.

33. Swahn E, Alfredsson J, Afzal R et al. Early invasive compared with a selective invasive strategy in women with non-ST-elevation acute coronary syndromes: a substudy of the OASIS 5 trial and a meta-analysis of previous randomized trials. Eur Heart J 2009; e-publisert 7.2.2009. 
34. Wallentin L, Lagerqvist B, Husted S et al. Outcome at 1 year after an invasive compared with a noninvasive strategy in unstable coronary-artery disease: the FRISC II invasive randomised trial. FRISC II Investigators. Fast revascularisation during instability in coronary artery disease. Lancet 2000; 356: 9-16.

35. Daly C, Clemens F, Lopez Sendon JL et al. Gender differences in the management and clinical outcome of stable angina. Circulation 2006; 113: 490-8.

36. Pepine CJ, Kerensky RA, Lambert CR et al. Some thoughts on the vasculopathy of women with ischemic heart disease. J Am Coll Cardiol 2006. 47: $30-5 \mathrm{~S}$.

37. Bugiardini R, Bairey Merz CN. Angina with «normal» coronary arteries: a changing philosophy. JAMA 2005; 293: 477-84.

38. Schroeder S, Achenbach S, Bengel F et al. Cardiac computed tomography: indications, applications, limitations, and training requirements: report of a writing group deployed by the Working Group Nuclear Cardiology and Cardiac CT of the European Society of Cardiology and the European Council of Nuclear Cardiology. Eur Heart J 2008; 29: $531-56$.

39. Klem I, Greulich S, Heitner JF et al. Value of cardiovascular magnetic resonance stress perfusion testing for the detection of coronary artery disease in women. JACC Cardiovasc Imaging 2008; 1 : 436-45.

Manuskriptet ble mottatt 20.1. 2009 og godkjent 7.5. 2009. Medisinsk redaktør Åslaug Helland. 